Meta

Journal des traducteurs

Translators' Journal

\title{
Gayspeak and Gay Subjects in Audiovisual Translation: Strategies in Italian Dubbing
}

\section{Irene Ranzato}

Volume 57, numéro 2, juin 2012

La manipulation de la traduction audiovisuelle

The Manipulation of Audiovisual Translation

URI : https://id.erudit.org/iderudit/1013951ar

DOI : https://doi.org/10.7202/1013951ar

Aller au sommaire du numéro

Éditeur(s)

Les Presses de l’Université de Montréal

ISSN

0026-0452 (imprimé)

1492-1421 (numérique)

Découvrir la revue

Citer cet article

Ranzato, I. (2012). Gayspeak and Gay Subjects in Audiovisual Translation: Strategies in Italian Dubbing. Meta, 57(2), 369-384.

https://doi.org/10.7202/1013951ar
Résumé de l'article

L'objectif du présent article est d'analyser la manière dont le langage des homosexuels est représenté à l'écran, ainsi que la façon dont les traducteurs et adaptateurs/doubleurs italiens ont traité le langage gay. Il s'agit d'examiner si les mots du lexique gay dans les langues anglaise et italienne couvrent des aires sémantiques similaires ou non, un déséquilibre entre les deux langues pouvant créer des problèmes de traduction. Par ailleurs, des exemples provenant de films et de programmes de la TV doublés permettront de vérifier si certaines caractéristiques de la langue gay sont substantiellement altérées dans les adaptations italiennes et si ces modifications sont dues à des contraintes déterminées par le vocabulaire utilisé pour définir l'idiolecte de cette communauté de langage ou, plutôt, à des contraintes manifestes ou latentes, imposées par la culture italienne, qui s'est ouverte aux thèmes homosexuels beaucoup plus lentement que le monde anglo-saxon.
Ce document est protégé par la loi sur le droit d'auteur. L'utilisation des services d'Érudit (y compris la reproduction) est assujettie à sa politique d'utilisation que vous pouvez consulter en ligne.

https://apropos.erudit.org/fr/usagers/politique-dutilisation/ 


\title{
Gayspeak and Gay Subjects in Audiovisual Translation: Strategies in Italian Dubbing
}

\author{
IRENE RANZATO \\ Imperial College, London, UK \\ Università di Roma Sapienza, Rome, Italy \\ irene.ranzato@libero.it
}

\begin{abstract}
RÉSUMÉ
L'objectif du présent article est d'analyser la manière dont le langage des homosexuels est représenté à l'écran, ainsi que la façon dont les traducteurs et adaptateurs/doubleurs italiens ont traité le langage gay. II s'agit d'examiner si les mots du lexique gay dans les langues anglaise et italienne couvrent des aires sémantiques similaires ou non, un déséquilibre entre les deux langues pouvant créer des problèmes de traduction. Par ailleurs, des exemples provenant de films et de programmes de la TV doublés permettront de vérifier si certaines caractéristiques de la langue gay sont substantiellement altérées dans les adaptations italiennes et si ces modifications sont dues à des contraintes déterminées par le vocabulaire utilisé pour définir l'idiolecte de cette communauté de langage ou, plutôt, à des contraintes manifestes ou latentes, imposées par la culture italienne, qui s'est ouverte aux thèmes homosexuels beaucoup plus lentement que le monde anglosaxon.
\end{abstract}

\section{ABSTRACT}

The purpose of this article is to analyse the fictional language of homosexuals as portrayed on the screen, as well as the way in which Italian translators and dubbing adapters have dealt with gayspeak. It means to explore whether the words of the gay lexicon in the English and the Italian languages cover similar semantic areas and whether any lack of balance between the two languages in this particular field may create problems for the translator. On the other hand, various examples from dubbed films and TV programmes will help to investigate whether some of the features of gayspeak are substantially altered in the Italian adaptations and whether these modifications are due to constraints determined by the vocabulary used to define the idiolect of this speech community or, rather, to overt and covert constraints imposed by a culture, the Italian, which has opened up to homosexual themes much more slowly than the Anglosaxon world.

\section{MOTS-CLÉS/KEYWORDS}

traduction audiovisuelle, doublage, homosexualité, manipulation, langue gay audiovisual translation, dubbing, homosexuality, manipulation, gayspeak

\section{Introduction}

In a pivotal scene of the comedy classic Bringing Up Baby (1938), ${ }^{1}$ the paleontologist David, played by Cary Grant, opens the door to an elderly lady. In this particularly chaotic moment of the film, David has been running around wearing a frilly woman's bathrobe and it is dressed in this way that he appears in front of the bewildered lady who exclaims: "Why are you wearing these clothes?." David's impromptu answer is a jump in the air and the words: "Because I just went gay all of a sudden!" 
This is the first time that the word gay was used in a feature film in the presumed sense of homosexual and not in its original meaning of happy (Boswell 1980: 43). The line itself was not included in the original script by Dudley Nichols and Hagar Wilde and it was probably ad libbed by Cary Grant himself. What makes the use of this word in the sense of homosexual a little more than presumed is the fact that gay had long acquired this meaning and had been commonly used as a slang word at least since the 1920s in the United States, although the term did not enter mainstream language until the 1940s in the USA and in the 1950s in England (Partridge 2002). ${ }^{2}$ What is interesting is that, because it was a slang word, it escaped the notice of the Hays Office, whose censorship code was particularly strict at the time. ${ }^{3}$

Notable as the Hollywood usage of the word gay is, I would like to shift the focus to the Italian dubbed version of Hawks's film, entitled Susanna, in which David's Italian answer to the lady's question about his peculiar choice of clothing is: Perché sono diventato pazzo, ecco perché! [Because I've turned mad, that's why!].

Gays in 1938 Italy were mad for two reasons: the first is that the very concept of a homosexual could never have made it past the fascist government's own censorship code; secondly and more importantly, as the word gay in the sense of homosexual entered the Italian lexicon as a loan word only in the late 1960s (De Mauro 1979: 103), it is more than likely that the Italian adapter did not know what Cary Grant was talking about.

This quotation helps me to introduce the object of this article which intends to highlight two main sensitive areas in the dubbing of the socalled gayspeak into Italian: first, the possible existence of overt and covert manipulative and censoring practices which, at all times and even today, may have tended to euphemize, dilute or alter homosexual content and, more simply, to suppress the words of homosexuality; secondly, the necessity of an assessment of the Italian gay lexicon as compared to the richness of the corresponding English terminology, in order to determine whether there exists objective problems for the translators who do not have a particular skill for making up neologisms. The presentation of a few case studies taken from films and TV programmes that have been dubbed into Italian at different periods will help me illustrate these two issues.

\section{The idiolect of a speech community}

The concept of speech community was first introduced by Saussure (1967/2009: 92) and received further definition in the course of the late 1960s and early 1970s, thanks to the contribution of sociolinguistics. According to Labov (1972: 120), "the speech community is not defined by any marked agreement in the use of language elements, so much as by participation in a set of shared norms." The term of speech community carries varied nuances according to the different scholars using it, so it is difficult to define it as an actual technical term (Mesthrie, Swann et al. 2005: 38). It is safe to say that the members of a speech community are people who have habitual contact with each other and have developed a shared use of the language, with a common lexicon and language practices. Fundamentally, as Mesthrie, Swann et al. (2005: 37) remark, "the term stresses that language practices may be equally diagnostic of the social coherence of a group, and may be a more natural boundary for sociolinguistic study than, say, geographical cohesion alone." 
The field of audiovisuals portrays plenty of speech communities suitable to the study of researchers: from the professional jargons of medical or legal TV series to the variously cohesive social groups which, for different reasons, have developed shared language practices. One of the most interesting idiolects spoken by a community is the socalled gayspeak, ${ }^{4}$ the modes and ways of homosexual communication.

Gayspeak itself is a word coined by Hayes in a paper first published in 1976 and more recently in a 2006 collection on language and sexuality edited by Cameron and Kulick. Hayes argued that homosexuals are America's largest subculture and that they (the men at least) have their own language. According to Hayes, homosexuals use gayspeak in three situations: the secret setting, in which it is necessary to express one's own sexuality with circumspection; the social setting, in which gays speak to other people they know to be gay; and the radical-activist setting, in which gays control and filter their language in what we today call politically correct ways. Hayes identifies a number of linguistic features that correspond to these settings, for example, "euphemism and innuendo in the secret setting, in-group slang in the social setting, and conscious avoidance or resignification of particular terms in the radicalactivist setting" (Hayes 1976/2006: 68-77).

This is not the place to tackle fundamental issues, namely the question of whether it is acceptable, in terms of political correctness but also of linguistic correctness, to draw general assumptions on gayspeak as if it were the language of a single community, while the social landscape is obviously varied and susceptible to innumerable distinctions. Podesva, Roberts et al., for instance, argue that:

labeling a linguistic feature as gay is at once too general and too specific. First, the assumption that there is a singular gay way of speaking homogenizes the diversity within the gay community [...]. Second, while labeling linguistic features as gay is too general, it also runs the risk of not being general enough. By simply assigning gay meanings to linguistic features, one reifies as gay certain linguistic features that are shared throughout society. (Podesva, Roberts et al. 2002/2006: 142)

For example, the same authors rightly remark that to define cooperative discourse as a specifically gay feature, as it is often the case, means ignoring its use by women and straight men.

While it is important to keep in mind these distinctions, my purpose here is the analysis of fictional homosexuals and of their fictional language as portrayed on the screen in modes and ways which may be realistic but are more often than not stereotyped. Even in the most naturalistic and politically correct examples, homosexuals on screen are often recognisable by a marked way of speaking often bordering on what is popularly known as camp. This kind of fictional speech is the focus of my article as well as the way in which Italian translators and dubbing adapters have dealt with gayspeak and with homosexual lexicon in particular. At issue here is the image of this speech community as portrayed in films with gay subjects, their fictional complexity and the relative simplification that tends to take place in terms of lexical choice and manipulation of contents.

According to Hayes, the richest features of social gayspeak are found in the lexicon, particularly in compound constructions, with queen being possibly the most widely employed stem word for building compounds used for a limitless series of images to describe sexual preferences (i.e. size queen), subculture types (queen of tarts, a pimp for hustlers), to make fun of a man's hobbies or interests (poker queen for 
someone who likes playing cards) or as an all-purpose term of derogation (Queen Mary for someone fat) (Hayes 1976/2006: 71). One of the most interesting themes related to lexicon is, I would argue, the way gay activists have managed to create new, more positive references for some of the most common, derogatory homosexual terms:

In 1969, gays began marching [...]. Words that had formerly referred only to one's sexual identification, like gay and straight, or that had been pejoratives, like dyke, faggot, and cocksucker, had become instead politically charged terms that affirmed the new identity of gays. To come out of the closet now has a political meaning; the phrase refers to the assumption of one's identity as a positive thing, something to be yelled in the streets, rather than hidden and whispered about behind closed doors. And once you are out of your closet, you no longer cringe when someone calls you a dyke or a faggot. To be a dyke or a faggot refers to one's political identity as a gay activist. Being gay no longer simply refers to loving one's own sex, but has come to designate a state of political awareness in which one no longer needs the narrowly defined sex-role stereotypes as bases for identity. (Stanley 1974/2006: 54)

Italian gay lexicon has also had a similar evolution, a similar positive turn as the one Stanley refers to, although the respective terms either struggled to find their way into mainstream language or were absorbed as loan words, thus keeping an exotic feel to them, a foreign ring. This testifies to the fact that, at least at the beginning, these words struggled to be absorbed by the target culture: gay, transgender, coming out, drag queen, are now words recognisable by most Italian people, but they are just about the only words of the homosexual jargon to have entered mainstream language. ${ }^{5}$ In the case of the English language, as early as 1941, Legman included 146 terms in his American glossary which contained "only words and phrases current in American slang, argot, and colloquial speech since the First World War, and particularly during the period between 1930 and 1940" (Legman 1941/2006: 19). According to the author, the glossary was far from exhaustive, though it was part of a longer list of 329 terms - the selection being words which were used exclusively by homosexuals. A great number of these words are now part of standard English or are slang words used also by the general public.

In this respect, a wide gap divides the two languages in terms of lexicon today and the gap was even wider in the past. This should be kept in mind when analysing the translation of earlier films. The lack of balance between the lexicons of the two languages, English and Italian, creates objective problems for the translator. Sometimes, a poor translation might not be due necessarily to a tendency to manipulation but simply to the lack of a lexical counterpart.

\section{3. "Acting within acting"}

Quite interestingly for researchers in the field of audiovisuals, gayspeak has developed an important cluster of images from stage and film. As mentioned by Hayes:

Famous Hollywood stars of the thirties and forties figure importantly, especially if the roles they play are campy or treat of tragic love. A melodramatic loser, for instance, is a Stella Dallas. A man who is suspected of actually enjoying his constant misfortune becomes a Camille or a Sarah Bernhardt (sometimes Sarah Heartburn). Stars such as Mae West, Bette Davis, and Carmen Miranda are mimed along with some of their 
famous scenes or routines probably because they exaggerate the various stereotyped roles that women play in general society. Gayspeak has, thus, an idea of acting within acting. Mimicking the tone, diction rhetoric, and speech mannerisms of those camp heroines would seem to show the subculture's perception of how seriously the dominant culture takes the language by which it maintains rigid images of sex sterotyping. At its very core, camp is the art of the put-down, especially of one's self and culture. (Hayes 1976/2006: 71)

This feature is part of a wider discourse which sees gayspeak as speaking from a certain place to a certain audience, as Leap (1997: XI) states, quoting Irigaray (1985: 135-136), who famously applied this definition to women's speaking.

The "acting within acting" (Hayes 1976/2006: 71) and the allusions to film stars of the past or other iconic figures are, indeed, a feature of gayspeak which is often portrayed in films and used stereotypically to depict campier characters. Sometimes a campy way of speaking may be used ironically by characters who normally have a more neutral mode of expression.

If this kind of allusion, as defined by Leppihalme (1997), in an audiovisual text are less than explicit or if they hint at people and characters who are not familiar to the target culture, Italian adaptations tend to erase this important feature of speech, thus making the idiolect less clear and defined, as can be seen in the films and TV series mentioned below.

\subsection{Angels in America}

The celebrated play by American writer Tony Kushner was first performed in London in $1992^{6}$ and became a TV miniseries, ${ }^{7}$ very faithful to the original work, directed by Mike Nichols in 2003. With its unique style, between the oneiric and the naturalistic, the play covers various issues, including the condition of homosexuals in Reagan's America in a period - 1985 - in which AIDS was still considered the gay plague. The rich plot is a mine of cultural, historical and literary references which make of Angels in America an important work, not only for theatre researchers and lovers, but also for translation studies scholars.

Both in the play and the film, the most theatrical camp speaker is Belize, an ex drag queen whose speech presents all the traits that Harvey (2004: 449-450) finds characteristic of gay camp talk: the preoccupation with sexual activity and a tragicomic awareness of the ephemeral nature of sexual desire; the ironic, feigned adherence to principles of decency; the inversion of gender-specific terms, the girl talk; the practice of renaming that includes the adoption of male names marked as queer, and the frequent use of French, which Harvey (2004: 451) defines one of verbal camp's most consistent devices in English, with its humorous nod to sophistication and cosmopolitanism.

Angels in America (2003) presents a wide range of other verbally nuanced characters as well as Belize. In the following scene, two of the protagonists, Louis and Prior, a homosexual couple, have just been to the funeral of Louis's grandmother (the words in bold, in all the examples, indicate the expressions which are relevant in the analysis of gayspeak):

(1) Louis: Sorry I didn't introduce you to... I always get so closety at these family things. 
Scusa se non ti ho presentato... avrebbero capito e non volevo che se ne accorgessero.

[Sorry I didn't introduce you... they would have understood and I didn't want them to realise.]

Prior: Butch. You get butch. (Imitating.) "Hi Cousin Doris, you don't remember me I'm Lou, Rachel's boy." Lou, not Louis, because if you say Louis they'll hear the sibilant $S$.

Omosessuale. Nascondere sempre i difetti. (lo imita) "Ciao, cugina Doris, ah, non ti ricordi di me? Sono Lou, il figlio di Rachel, Lou." Non dire Louis o ci si accorge della tua $S$ sibilante.

[Homosexual. Always hide the faults. (Imitating) "Hi Cousin Doris, ah, you don't remember me? I'm Lou, Rachel's son, Lou." Don't say Louis or they'll notice your sibilant $\mathrm{S}$.]

Louis: I don't have a...

Io non ho la S sibilante.

[I don't have a sibilant S.]

Prior: I don't blame you, hiding. Bloodlines. Jewish curses are the worst. I personally would dissolve if anyone ever looked me in the eye and said "Feh."

Fortunately WASPs don't say "Feh." Oh, and by the way, darling, cousin Doris is a dyke.

Fai bene a nasconderlo, almeno ai tuoi parenti. Gli insulti di voi ebrei sono feroci. Io mi sentirei morire se uno di loro mi dicesse in faccia "Feh." Per fortuna i Protestanti non usano il termine "Feh." E, tesoro, per rimanere in argomento, la cugina Doris è lesbica.

[You do well in hiding it, at least to your relatives. The insults of you Jewish people are fierce. I would feel like dying if one of them said "Feh" to my face. Fortunately Protestants don't use the term 'Feh.' And, treasure, by the way, your cousin Doris is a lesbian.]

Louis: No. Really?

No. Davvero?

[No. Really?]

Prior: You don't notice anything. If I hadn't spent the last four years fellating you I'd swear you were straight.

Non l'hai notato. Se non fossero quattro anni che faccio sesso con te direi che sei innocente.

[You didn't notice. If I hadn't spent the last four years having sex with you I'd say you were innocent.]

Louis: You're in a pissy mood. Cat still missing?

Sei di pessimo umore. Il gatto è tornato?

[You're in a very bad mood. Has the cat come back?]

Prior: Not a furball in sight. It's your fault.

Neanche l'ombra. Ed è solo colpa tua.

[Not a shadow. And it's only your fault.]

Louis: It is?

Dici sul serio?

[Are you serious?]

Prior: I warned you, Louis. Names are important. Call an animal "Little Sheba" and you can't expect it to stick around. Besides, it's a dog's name. [...] I did my best Shirley Booth this morning, floppy slippers, housecoat, curlers, can of Little Friskies; "Come back, Little Sheba, come back..." To no avail. Le chat, elle [sic] ne reviendra jamais, jamais...

Ti avevo avvertito Louis, il nome è importante. Hai voluto chiamarlo Little Sheba, che è il nome di un cane, e se l'è squagliata. Anche i gatti hanno il 
loro amor proprio. [...] Ho dato il meglio di me stamattina sulla porta di casa. Pantofole, bigodini, vestaglia e agitando la scatola di croccantini. “Torna da me, Little Sheba, torna da me." Niente da fare. Le chat, elle ne reviendra jamais, jamais....

[I had warned you, Louis, the name is important. You wanted to call it Little Sheba, which is a dog's name, and it beat it. Cats, too, have their own pride. [...] I gave my best this morning on the doorstep. Slippers, curlers, housecoat, and shaking the box of biscuits. "Come back to me, Little Sheba, come back to me." To no avail. Le chat, elle ne reviendra jamais, jamais...]

(Angels in America 2003; Angels in America 2003; my back translation)

This excerpt is a compendium of the typical problems presented by gayspeak and, incidentally, by culture-bound elements in translation. And it is revealing of the euphemizing strategies that even a generally faithful adaptation is prone to. It is worth remembering that Angels in America was first broadcast on Italian TV on World Aids Day in 2004 so the audience it addressed was aware of the theme and hence prepared.

The opening line of the Italian exchange is already relevant as it reveals the lack of homosexuality-related terms corresponding to the rich variety of English. Or, to be more precise, it shows how the Italian lexicon of homosexuality lacks the inventiveness of English, shies away from neologisms and prefers to resort to borrowing.

In this particular case, the lack of a concise term to translate butch - the definition for a masculine and aggressive type of lesbian - leads to a modification of the sense of Prior's first line. In his usual caustic style, in the original dialogue Prior defines Louis's behaviour during the encounter with his family as butch. Instead of resorting, as it does, to the general term of omosessuale [homosexual] and hinting vaguely at nascondere sempre i difetti [always hide the faults], the Italian adaptation could have used the more banal word 'macho,' which is also used in Italian, perhaps losing the homosexual and ironic connotations but at least sticking more closely to the meaning of Prior's words. The term butch is used as a loan word by more cosmopolitan homosexuals in Italy today but it is strictly limited to gay usage and not common at a colloquial level. The term actually has an Italian equivalent: camionista [truck driver]. But this slang meaning of the word is, again, limited to gay circles and generally considered old-fashioned.

Another colourful term is substituted in Italian by a more standard one when Prior mentions that cousin Doris is a dyke. Dyke, originally a pejorative term for lesbian, is today a colloquial term in English. To translate this word into Italian, one would have to choose between the standard word lesbica (the adapters' option) or the slang term, frocia. The fact is that frocia, the feminine of frocio, which is the most common derogatory word for homosexual in Italian, has not entered the general lexicon as $d y k e$ has in English. Its impact is harsher and still offensive, not in keeping with the generally sanitising strategy of this adaptation. The colour of words like butch and dyke is thus lost in Italian for lack of corresponding terms which could cover exactly the same semantic areas.

The word closety, although not exclusive of the gay vocabulary, is nonetheless often used in the sense of a person who is reserved about his/her sexual orientation, but also in this case Italian lacks a corresponding term which has the same expressive conciseness. The adapters have opted for a phrase - avrebbero capito [they would have understood] - which, by modulating the reference, still conveys Louis's reservedness. 
In the English dialogue, some features of gayspeak, as indicated by Harvey (2004: 449-451), can also be found. The French phrase in the last line of the excerpt is kept in Italian, as the use of French in this language has the same sophisticated overtones that it has in English. But the characteristic preoccupation with sexual activity alluded to by Harvey (2004: 449), which is a common feature at least of fictional homosexuals, is here severely euphemized when transferred into Italian. Thus, If I hadn't spent the last four years fellating you I'd swear you were straight becomes the rather colourless Se non fossero quattro anni che faccio sesso con te direi che sei innocente [If I hadn't spent the last four years having sex with you I'd say you were innocent], which does not do any justice to the always explicit and rather crude idiolect of Prior. The word innocente - here in the sense of both 'naif' and 'pure,' someone who does not entertain any impure sexual thought - is interesting in its use here: it implies that Louis is in fact far from "innocent" and it is used in substitution of the original straight, thus implying that straight is "pure" and homosexual is "impure."

One more gayspeak feature included in the original dialogue are the references to the Hollywood imagery. Little Sheba was the name of a dog in a popular $1952 \mathrm{film}$, Come Back, Little Sheba, by Daniel Mann, in which the protagonist, played by Shirley Booth, waits for months for her dog to come back. The handling of the original lines in Italian is awkward. Unfortunately, the name Little Sheba does not ring any bell to Italian audiences, as Mann's film is not so popular in this country (although it was distributed with the literal title of Torna, piccola Sheba). The adaptation resorts to the habitual strategy of elimination of cultural elements by ignoring the reference to the actress Shirley Booth, whose name is actually not well known in Italy. Prior, who acts out the role of Booth by imitating her explicitly in the original, gives his "best" in the Italian version and does not mention the name of the actress. ${ }^{8}$

Incidentally, this excerpt shows how even an apparently faithful adaptation ignores culture specific nuances. For example, Sheba for Italians is actually a cat name, probably because of a famous commercial for cat food (known all over the world and thus a transnational more than a culture specific element). That is why, once the "bonds of belonging" (Pym 2010) have been cut loose from the film title which inspired Prior's words, the line in Italian does not really work.

On the other hand, the elimination of the cat food name Little Friskies, known in Italy as simply Friskies, reveals the antipathy for brand names that TV adaptations into Italian often show. The general term of croccantini (cat or dog biscuits, literally crunchy biscuits) was preferred.

The word WASP, always a problem for Italian translators for its concise rendering of a cluster of concepts, White Anglo-Saxon Protestant, was transposed by selecting only the last element of the acronym, Protestanti [Protestants]. The choice is unimaginative but coherent as it counterposes directly Protestants to Jews, eliminating the social connotations by simplifying the tensions in terms of religious affiliation.

By evoking the image of himself in housecoat, slippers, curlers and shaking the box of biscuits, Prior is acting the drag queen that we will see him visually enacting in other parts of Angels in America (2003). But in the Italian version, he is not imitating a Hollywood star, he is just calling his cat back. In this early dialogue - the first important one between Louis and Prior, the presentation of their characters - we know Prior for what he is: funny, vulnerable, crude, and sarcastic. His idiolect in 
Italian is not so clearly pinpointed, especially because of the elimination of an important feature of gayspeak, i.e. the "acting within acting" (Hayes 1976/2006: 71).

This one example shows the many, meaningful departures from the original of a supposedly faithful, respectful dubbing adaptation which was well aware of the theme it was handling and of its target audience, if not of the stature of a work that Bloom (1994) included in his Western Canon of the most important works of literature of all times.

\section{Translating homosexual into heterosexual}

The following examples, taken on purpose from different media - television and cinema - and different times - the present decade and the 1970s - are instances of a more conscious design to adapt a homosexual discourse to a heteronormative view of homosexuals. This is achieved by manipulating the words of gayspeak and, more boldly, by censoring or altering gay contents. It is much more than just a matter of sanitisation: it is the purposeful dismantling of a network of associations which in the original texts overtly relate to a gay imaginary.

\subsection{Six Feet Under (2001-2005)}

From June 2001 to August 2005, the American channel HBO broadcast the five seasons of Six Feet Under, ${ }^{9}$ a drama series created by Alan Ball and tinged with black humour. The series centres on the life of a family of undertakers, the Fisher family, and on the complex relationships between Ruth, the mother, who in the first episode becomes the widow of Nathaniel senior, and her three children: David, Nate and Claire. David, the most interesting of the three, is a tormented homosexual who stubbornly soldiers on in a family business he does not particularly like. What with the problems I have mentioned and the corpses that the Fishers daily have to sew up and make up in order to make them presentable at open casket funeral viewings, there was more than sufficient material to concern the people responsible for the Italian version of this TV programme.

The adaptation of the first of the five seasons especially shows some significant manipulations: the programme was very different from anything ever shown till then on Italian television, it was bold, it tackled sensitive issues (sex, drugs, death, racism) with sarcastic humour, so it was probably difficult for the broadcasters and adapters to determine its ideal target audience. That is why, in the whole series but especially in the first episodes, we find significant departures from the original which affect both the content and the style of the dialogues which lose part of their sarcastic witticism.

In this excerpt (2) from the series (season 1, episode 3), we can see how the Hollywood imagery is abandoned even though the actors mentioned are internationally known. David and Keith, a homosexual couple, are in a shop, choosing a ceiling fan:

(2) David: (pointing to a ceiling fan) What about that one?

Quello lassù ti piace?

[Do you like the one up there?]

Keith: That's a little too Mayberry for me. Something simple and clean, like the ones that hang in the deserted truck stop... and that handsome drifter blows into town. 
Un po' troppo country per me. Voglio qualcosa di semplice, di lineare, come quelli dei bar che si vedono nei film, quando il protagonista fa il suo ingresso in città.

[A bit too country for me. I want something simple and clean, like those in the bars you see in films, when the protagonist makes his entrance in town.]

David: Of course. What about that one?

Capito il concetto. Che te ne pare di quello?

[I get the concept. What do you think about that one?]

Keith: Uh... Not bad. I could see Ava Gardner lying beneath it, plotting to steal Clark Gable away from Grace Kelly.

$\mathrm{Mm}$, già meglio. Buono per stare al fresco a riflettere, aiuterebbe anche te a prendere la decisione giusta.

$[\mathrm{Mm}$, that's better. Good to reflect in the cool, it would help even you take the right decision.]

(Six Feet Under 2001-2005; Six Feet Under 2004-2008;

my back translation)

The lines reported above are only an instance of a general and seemingly conscious strategy of banalisation and euphemization of the sophisticated original dialogue exchanges. The example shows how the Italian translation neglects some of the typical (or stereotypical) features of gayspeak, for what it seems to be a lack of an appropriate analysis of this particular idiolect. A whole gay imaginary is lost in translation. Not only are all the famous Hollywood names, and John Ford's film Mogambo (1953), ${ }^{10}$ which is not quoted but evoked, not transferred to the Italian version, but the gay fantasy of the handsome drifter becomes the neutral image of il protagonista [the protagonist]. Incidentally, the stylistic note of Mayberry, from the title of an American TV series set in an idyllic country town, is translated into the less colourful country [country]. The adjective country, which is of common usage in Italian as a loan word, conveys the sense of rustic, which is implied in Mayberry, but not the atmosphere of a bucolic small town, which is also part of the original sense.

As for gender-related issues, what is interesting in Six Feet Under is that, whenever possible, an Italian heterosexual discourse is superimposed to the English homosexual one. See, for example, the following dialogue between Ruth Fisher and her son David in the pilot episode of the series. In this first episode, David has not yet come out and he is talking to Ruth about his father's brand new hearse:

(3) Ruth: I think your father is having some sort of midlife crisis.

Tuo padre ci teneva, si è fatto un regalo per la crisi di mezza età.

[Your father wanted it very much, he bought himself a present for his midlife crisis.]

David: It would have made so much more sense to invest in re-paneling for the chapel or adding coffee bars to the slumber rooms.

Era meglio investire per ridrappeggiare la cappella o mettere le macchinette del caffè nella camera ardente.

[It would have been better to invest in re-paneling for the chapel or adding coffee bars to the slumber rooms.]

Ruth: Well, I'd much rather he buy himself a fancy new hearse than leave me for a younger woman, or a woman my age for that matter, or, heaven 
forbid, a man, like my cousin Hannah's husband did. God sure has dealt that woman some blows in this life.

E comunque sempre meglio che si sfoghi con un'auto nuova piuttosto che tradendomi con una ragazzina o con una donna della mia età. Gli uomini come il marito di mia cugina Hannah il cielo li dovrebbe castigare. Il Signore ha riservato dure prove a quella povera donna.

[Anyway it's always better that he satisfies himself with a new car than betray me with a young girl or a woman my age. Heaven should punish men like my cousin Hannah's husband. God has reserved that poor woman some hard trials.]

(Six Feet Under 2001-2005; Six Feet Under 2004-2008; my back translation)

In the original dialogue, the husband of Ruth's cousin has left his wife for another man, while in Italian this detail is suspiciously omitted and Hannah's husband is portrayed as the usual heterosexual rascal. This translation has the added downside that it ignores David's facial expression that can be seen on screen clearly perturbed by Ruth's words. The image somehow betrays the Italian words of the dialogue in such a way as to make the two codes, the verbal and the visual, not fully synchronised. The example reported above is the most noteworthy example of "translation of homosexual into heterosexual" that permeates through the whole programme.

The next example (season 1, episode 10) from this series shows how the reasonably general English terms of butch and dyke are not acknowledged in the target version. Angela, a heterosexual woman, is talking to another heterosexual female:

(4) Angela: I don't want to be one of those menopausal women, ya know, that goes all dykey with a butch haircut.

Non credo che diventerò mai una di quelle donne in menopausa con il taglio da uomo fatto con lo stampino.

[I don't think I'll ever become one of those menopausal women with a custom-made man haircut.]

(Six Feet Under 2001-2005; Six Feet Under 2004-2008; my back translation)

A more literal translation would have risked not being understood by Italian audiences for which the kind of haircut referred to is only a "man" haircut. This example reveals much more than the lack of an appropriate target lexicon. It shows an old-fashioned view of homosexuality which manages to absorb, through dubbing, the contemporary discourse on homosexuality which is in the original text. As Cameron and Kulick note, today we understand homosexuality as an attraction of like to like but "as recently as 50 years ago, homosexuality was more commonly understood as a matter of gender 'inversion"' (Cameron and Kulick 2006: 4), homosexuals were effeminate males and masculinized females. For the old-fashioned mentality revealed by this dubbing, lesbians are women who look like men, so going dykey naturally translates into something that means "look like a man."

In different ways, the three examples show one of the leitmotifs of the Italian adaptation of Six Feet Under: the purpose to transform a homosexual discourse into a heterosexual one, a purpose achieved by manipulating both contents and speech. 


\subsection{The Boys in the Band (1970)}

Other, much earlier examples of superimposition of a heterosexual veneer over homosexual contents can be found in Italian dubbing for the cinema. If some of these adaptations can be striking - see for example the Italian translation of the film Suddenly, Last Summer (1959), ${ }^{11}$ entitled Improvvisamente l'estate scorsa (1959), which I have discussed elsewhere (Ranzato 2009) - my purpose with this paper is to show the extent to which gayspeak and gay contents were manipulated in subtler ways in more recent audiovisual products.

This subtlety is a direct consequence of a shift in the characterisation of homosexual people on screen. Roughly from the 1970s onwards, cinema has gradually portrayed more multi-faceted, more complex, more liberated homosexuals than the either parodistic or the tortured and closeted gay men and women of earlier cinema.

Often considered a turning point in the history of queer cinema as one of the first, full screen portrayals of male homosexuality, the film The Boys in the Band $(1970)^{12}$ is probably the first example of an explicitly all-gay plot.

If gayspeak owes much of its substance to films and acting, cinema has certainly given something in return and films such as The Boys in the Band have made gayspeak words like auntie, butch, cruise, drag, queen, and gay more familiar to the general public.

The film was based on a successful off-Broadway play by Mart Crowley. ${ }^{13}$ It presents a group of mostly stereotyped homosexual characters (except maybe for the couple of Hank and Larry) who meet to celebrate the birthday of one of them. In Italy, the film was entitled Festa per il compleanno del caro amico Harold (1970) [Birthday Party for the Good Friend Harold; my back translation], and was distributed in two versions: one of about ten and the other one of about twenty minutes shorter than the original.

The Italian versions sanitised many of the crudest passages in the dialogue. This is evident in the following exchange between two of the protagonists which, in the original, features some traits recognised as typical of gayspeak, namely the inversion of masculine/feminine pronouns and the reference to the sibilant $S$ :

(5) Emory: Yeah, they'd love to meet him - her. I have such a problem with pronouns.

Sarebbe bello incontrarsi con lui... con lei, ho una tale difficoltà con $i$ pronomi.

[It would be nice meeting him... her, I have such a problem with pronouns.]

Alan: How many esses are there in the word pronoun?

Confonde sempre il maschile col femminile.

[He always confuses masculine and feminine.]

Emory: How'd you like to kiss my ass - that's got two or more essessss in it! Prova a farti dare un bacio e vedrai che non mi confondo più.

[Let me give you a kiss and you'll see I won't get confused anymore.]

Alan: How'd you like to blow me!

Con quella bocca da puttana?

[With that mouth of a whore?]

(The Boys in the Band 1970; Festa per il compleanno del caro amico Harold 1970; my back translation) 
If the reference to the inverted pronouns is faithfully rendered, the one to the sibilant $S$ is completely ignored in favour of a pleonastic comment. The explicit sexual exchange is sanitised, as vivid representations of sexual practices are generally censored in favour of a view of homosexuality seen as an inversion of normal heterosexual desire: Alan's line (How'd you like to blow me!) becomes in Italian a joke on Emory having the mouth of a (female) whore. As in Six Feet Under, this is another instance of how the Italian translation filters the original text in such a way as to portray homosexuals as people whose gender is inverted: Emory proposes to kiss Alan, with the mouth of a woman.

One more feature of gayspeak, the references to French, is ignored in the Italian version:

(6) Donald: Surgery, so early in the evening?

Sono appena le sette e già ti restauri?

[It's hardly seven and you're already restoring yourself.]

Michael: Cunt! That's French, with a cedilla. I've just got to comb my hair for the thirty-seventh time.

Schiatta o crepa, come preferisci. Ah, devo pettinarmi di nuovo per la trentasettesima volta.

[Snuff it or drop dead, as you prefer. Ah, I have to comb my hair for the thirty-seventh time.]

(The Boys in the Band 1970; Festa per il compleanno del caro amico Harold 1970; my back translation)

The original dialogue has an ironic connotation suggested by the implausible use of some purely imaginary French: an incongruous reference to a metalinguistic cedilla for a vulgar and obscene cunt, a word which of course does not have any cedillas. It is a way to render mockingly gentler and more refined this English taboo word whose impact is always quite strong. The elimination of this funny element in Italian contributes to making Michael a generally more unpleasant and bitter character. The violence of the word is not eliminated, but rendered, again, more unpleasant by using the phrase schiatta o crepa [snuff it or drop dead] which may be not obscene but has no trace of irony. The overall strategy followed in this adaptation is to depict the homosexual world in a much more negative light than the original. The characters in The Boys in the Band may be sad but are never as sour and resentful as the ones in Festa per il compleanno del caro amico Harold.

In this homosexual comedy on homosexuals, the irony directed to heterosexuals is often subtly reverted in translation, as in the following example, where the Italian version of Donald does not make fun of the way some heterosexual men sit but of the way some homosexuals supposedly walk, thus turning irony into selfdeprecation:

(7) Donald: Michael, don't insult me by giving me any lecture on acceptable social behavior. I promise to sit with my legs spread apart and to keep my voice in a deep register.

Per favore adesso non insultarmi dicendomi come ci si comporta nella buona società. Ti prometto di non camminare dimenando il culo e di tenere la voce su un registro basso. 
[Please don't insult me by telling me how to behave in the good society. I promise not to walk wiggling my ass and to keep my voice in a low register.]

(The Boys in the Band 1970; Festa per il compleanno del caro amico Harold 1970; my back translation)

\section{Conclusions}

This analysis clearly demonstrates that the translation strategies used in Italian to render the original gayspeak have suffered from the bias and preconceptions of a culture, the Italian, which has opened up to homosexual themes much more slowly than the Anglosaxon world. One of the first consequences of this state of affairs is that the language of homosexuals has long remained in Italy the language of a ghetto and even today the relatively poor lexicon available is an objective obstacle even for the most unprejudiced translator.

Issues relative to the make-up of the potential target audience and the time of broadcast seem to be at the heart of some translation strategies. In this sense, for example, as we have seen with Six Feet Under (2001-2005), pilot episodes and first seasons in general, as well as programmes broadcast in prime time, tend to be more censored than others, probably because they have yet to build an audience and that audience has to be as large as possible in the first instance. Once its target public is somewhat established, there is space for more freedom, meaning here the freedom to be more literal and faithful to the original. More freedom is also granted to comedies with explicit homosexual themes. Programmes like the sitcom Will \& Grace $(1998-2006)^{14}$ are less censored than drama and realism, because homosexuality is still a subject which is best dealt with through laughter.

The Italian adaptation of many audiovisual programmes with gay content purposely perpetuates, at best, an old-fashioned and out-of-date view of homosexuality, primarily focussed on the inverted sexual desires of tormented figures. This interpretation betrays the content and the style of films and other programmes which, more and more often, in the course of the last decades, have depicted homosexual characters in a much more positive light. This manipulative operation is carried out by turning the positive discourse into a negative one and by transforming the words of liberation and pride into words of self-deprecation and ambiguity. In the worst cases, homosexuality is not even acknowledged and it is translated into a heterosexual and normalising lexicon.

The lack of an Italian vocabulary rich in homosexual terms of common usage is an objective obstacle for the translator, and it also reveals to what extent issues related to homosexuality are still closeted in Italy and struggle to come out into the open in their own speaking terms.

\section{ACKNOWLEDGMENTS}

I thank Serena Izzo for her insights on some of the examples in section 4.2. 


\section{NOTES}

1. Bringing Up Baby (1938): Directed by Howard Hawks. USA.

Susanna (1939): Italian version of Bringing Up Baby (1938). Dubbing by C.D.C. - Compagnia Doppiatori Cinematografici (1939) and redubbing by C.D. - Compagnia Doppiatori (1978).

2. Partridge, Eric (2002): A Dictionary of Slang and Unconventional English. London / New York: Routledge.

3. The Hays code contained strict censorship guidelines in force in the USA from 1930 to 1968, originally created by William H. Hays, President of the Motion Picture Association of America.

4. There are various definitions, with varied nuances, of this particular idiolect, including - among the most successful - camp talk. Please refer to Cameron and Kulick (2006), for an overview.

5. It must be noted, however, that Italian has an evident penchant for loan words as means of appropriation of the exotic.

6. Kushner, Tony (1991/2004): Angels in America: A Gay Fantasia on National Themes. Part One: Millennium Approaches. $2^{\text {nd }}$ ed. London: Nick Hern Books.

Kushner, Tony (1991/1994): Angels in America: A Gay Fantasia on National Themes. Part Two: Perestroika. London: Nick Hern Books.

7. Angels in America (2003): Directed by Mike Nichols. USA.

Angels in America (2003): Italian version of Angels in America (2003). Dubbing by A.A.C. - Award Art Communication.

8. In the stage production of Angels in America of Compagnia dell'Elfo, which was touring Italy in the end of 2010/beginning of 2011, the Italian adapters chose very aptly to translate Sheba with Lassie. After the huge success of the 1943 film Torna a casa, Lassie! (Lassie Come Home 1943), Lassie has become, also in Italy, the dog's name par excellence.

Lassie Come Home (1943): Directed by Fred McLeod Wilcox. USA.

Torna a casa, Lassie! (1948): Italian version of Lassie Come Home (1943). Dubbing and redubbing by C.D. - Compagnia Doppiatori.

9. Six Feet Under (2001-2005): Directed by Alan BALl. USA.

Six Feet Under (2004-2008): Italian version of Six Feet Under (2001-2005). Dubbing by EDIT.

10. Mogambo (1953): Directed by John ForD. USA. Mogambo (1954): Italian version of Mogambo (1953).

11. Suddenly, Last Summer (1959): Directed by Joseph Mankiewicz. USA.

Improvvisamente l'estate scorsa (1959): Italian version of Suddenly, Last Summer (1959). Dubbing by C.D.C. - Compagnia Doppiatori Cinematografici.

12. The Boys in the Band (1970): Directed by William FrIEDKIN. USA.

Festa per il compleanno del caro amico Harold (1970): Italian version of The Boys in the Band (1970).

13. Crowley, Mart (1968): The Boys in the Band, first performance directed by Robert Moore at Theater Four, New York, 14 April 1968.

Crowley, Mart (2008): The Boys in the Band. New York: Alyson Books.

14. Will \& Grace (1998-2006): Directed by David Конаn and Max Мuтснліск. USA.

Will \& Grace (2003-2007): Italian version of Will \& Grace (1998-2006). Italian dubbing by Multimedia Network.

\section{REFERENCES}

Bloom, Harold (1994): The Western Canon: The Books and School of the Ages. Appendices. New York: Harcourt Brace \& Company.

Boswell, John (1980): Christianity, Social Tolerance, and Homosexuality. Chicago: University of Chicago Press.

Cameron, Deborah and Kulick, Don, eds. (2006): The Language and Sexuality Reader. London: Routledge.

De Mauro, Tullio (1979): Lessico dell'omosessualità. In: Riccardo Reim, Laura Di Nola and Antonio Veneziani, eds. Pratiche innominabili. Violenza pubblica e privata contro gli omosessuali. Milano: Mazzotta, 98-112.

Harvey, Keith (2004): Translating camp talk. Gay identities and cultural transfer. In: Lawrence Venuti, ed. The Translation Studies Reader. London: Routledge, 446-467. 
Hayes, Joseph J. (1976/2006): Gayspeak. In: Deborah Cameron and Don Kulick, eds. The Language and Sexuality Reader. London: Routledge, 68-77.

Irigaray, Luce (1985): This Sex Which Is Not One. Ithaca: Cornell University Press.

Labov, William (1972): Sociolinguistic Patterns. Philadelphia: University of Pennsylvania Press.

Leap, William L. (1997): Word's Out. Gay Men's English. Minneapolis/London: University of Minnesota Press.

Legman, Gershon (1941/2006): The language of homosexuality: an American glossary. In: Deborah Cameron and Don Kulick, eds. The Language and Sexuality Reader. London: Routledge, 19-32.

Leppinalme, Ritva (1997): Culture Bumps. An Empirical Approach to the Translation of Allusions. Clevedon: Multilingual Matters.

Mesthrie, Rajend, Swann, Joann, Deumert, Andrea, et al. (2005): Introducing Sociolinguistics. Edinburgh: Edinburgh University Press.

Podesva, Robert J., Roberts, Sarah J. and Campbell-Kibler, Kathryn (2002/2006): Sharing resources and indexing meanings in the production of gay styles. In: Deborah CAmeron and Don Kulick, eds. The Language and Sexuality Reader. London: Routledge, 141-150.

Pym, Anthony (2010): Translation and Text Transfer. An Essay on the Principles of Intercultural Communication. Tarragona: Intercultural Studies Group.

Ranzato, Irene (2009): Censorship or "creative" translation?: The Italian experience from Tennessee Williams to Woody Allen to Six Feet Under. In: Federico M. Federici, ed. Translating Regionalised Voices in Audiovisual Translation. Roma: Aracne, 43-69.

Saussure, Ferdinand de (1967/2009): Corso di linguistica generale. (Translated by Tullio De Mauro) Roma/Bari: Laterza.

Stanley, Julia Penelope (1974/2006): When we say “Out of the closets!.” In: Deborah Cameron and Don Kulick, eds. The Language and Sexuality Reader. London: Routledge, 49-55. 